\title{
Incidence of Maize Streak Disease in Maize Cultivated During Late Cropping Season in Three Agricultural Zones of Benue State, Nigeria
}

\author{
${ }^{1}$ TIME, I; ${ }^{2}$ NWOGWUGWU, JO; *3BATCHO, AA \\ ${ }^{l}$ Department of Crop and Environmental Protection, University of Agriculture, Makurdi, Nigeria \\ ${ }^{2}$ Department of Forest Conservation and Protection, Forestry Research Institute of Nigeria \\ ${ }^{*}$ Faculty of Agriculture \& Environmental Sciences, Catholic University of the West Africa Cotonou, Benin \\ *Corresponding Author Email: anicetbatcho1@gmail.com
}

\begin{abstract}
Maize, an important staple crop is emerging as cash crop particularly for smallholder farmers in Nigeria. This paper evaluates the frequency of maize streak disease on maize sown during late cropping season in three agricultural zones of Benue State, with three maize cultivars; Super 98, Obasuper 1 and a local cultivar at the University of Agriculture Makurdi Research Farm using standard methods. Maize plots were sampled for streak disease from July to November. Data were analysed using descriptive statistics and ANOVA with means separated using $\operatorname{FLSD}_{(\mathrm{p}=0.05)}$. Spread of maize streak was low $(<20.0 \%)$ across the agricultural zones. It was, however, significantly different $(\mathrm{p} \leq 0.05)$ among the zones with $17.2 \%$ average, although reached $19.2 \%$ at Zone B in one occasion. Streak severity was equally significant $(\mathrm{p} \leq 0.05)$ but high $(3.6 \%)$ across zones, reaching its peak, 3.7 at Zone C while zone B (3.4) was least. Disease spread among the LGAs in the State equally differed significantly $(\mathrm{p}<0.05)$. Gwer West $(21.8 \%)$ and Otukpo $(19.3 \%)$ had the highest spread. Lowest percentage spread of $12.7 \%$ and $14.0 \%$ were recorded in Konshisha and Katsina Ala, respectively. Streak severity also differed statistically $(\mathrm{p}<0.05)$ among the LGAs. Ado and Konshisha were highest with 3.9 and 3.7, respectively while Gwer West, which was highest for disease spread was least in severity. Disease spread in maize experimental plots was more or less comparable to spread in farmers' fields. It was low averaging $10.3 \%$, in plots while severity of disease was high $(\geq 3.5)$ in experimental plots.
\end{abstract}

DOI: $\underline{\text { https://dx.doi.org/10.4314/jasem.v24i8.20 }}$

Copyright: Copyright $(02020$ Time et al. This is an open access article distributed under the Creative Commons Attribution License (CCL), which permits unrestricted use, distribution, and reproduction in any medium, provided the original work is properly cited.

Dates: Received: 30 May 2020; Revised: 03 July 2020; Accepted: 05 August 2020

Keywords: Benue State, Disease spread, Late season, Maize streak, Zea mays

Maize (Zea mays L.) is the most important food crop in the world after rice and wheat (IITA, 2005). The crop remains one of the major cereals grown in the sub-savanna region of Nigeria (Fatima and Abdul, 2005). Being one of the major sources of carbohydrates, maize is a staple for several million people in Africa and a constituent in livestock feed (Romney et al., 2003). Indeed, maize is fast becoming the most preferred crop since it is always one of the first to be harvested for food in the hunger period. The crop has always been patronized over any other crop including cassava (Fakorede, 2001). When eaten at the immature stages, maize is noted to yield large quantities of vitamins $\mathrm{A}$ and $\mathrm{C}$. As a grain crop in Nigeria, its importance is more on the economic value and not on the number of farmers engaged in the cultivation only.As a subsistence crop in Nigeria, maize production has gradually risen to industrial levels with many agro-based industries depending upon as raw material (Iken and Amusa, 2004). Current production of maize in the country stands at 10.2 million metric tonnes, cultivated on 4.9 million ha of land with average production of $2.1 \mathrm{tmm} / \mathrm{ha}$ (FAO 2018). This statistic puts Nigeria behind other African countries like South Africa, producing greater tonnage on less hectarage. Again mean production in the country is low when compared to that of the Globe (5.9 $\mathrm{tmm} / \mathrm{ha}$ ). Low output in production has partly been attributed to frequent biotic and abiotic stresses including diseases outbreaks, drought and poor farming practices (Morris et al., 1999). Maize streak caused by Maize streak virus (MSV) is the most economically important virus of maize in sub Saharan Africa (Thottappilly et al., 1993). Yield losses of 70 up to $100 \%$ have been reported (Kim et al., 1981). Grain yield reduction is most serious particularly during the late cropping season once there is a prolonged drought spill. Generally, MSV is not seed transmitted, thus ecology of the disease depends completely on movement of the vectors feeding and multiplying freely on common cereals and annual grasses leading to large scale infection of the plant. Maize breeding programmes targeting genes that are tolerant to the virus or vector for management are no longer major programmes in Nigeria. Also, continuous yearly surveys in farmer's maize fields which would have being sources of current data on status of the disease have been inadequate. Hence, there is a growing gap in knowledge on the status of the disease in the country, particularly in Benue State. This study was therefore initiated to investigate the extent of spread of maize streak disease in maize cultivated during late cropping season in three agricultural zones of Benue State, Nigeria. 


\section{MATERIALS AND METHODS}

Field survey: Survey was carried out among maize producing areas in three agricultural zones of Benue State: Zone A, B and C (Avav et al., 2010). Two Local Government Areas (LGAs) were selected at random in each zone and a total of six LGAs were surveyed from July - September in the 2016 cropping season. Katsina-Ala (lat. $7^{0} 47^{0} \mathrm{~N}$, long. $9^{0} 18^{0} \mathrm{E}$ ), Konshisha (lat $7^{0} 15^{0} \mathrm{~N}$ long. $9^{0} 6^{0} \mathrm{E}$ ) LGAs were selected from Zone A, Makurdi (lat $7^{0} 74^{0} \mathrm{~N}$ long. $8^{0} 51^{\circ} \mathrm{E}$ ) and Gwer West (lat $7^{0} 18^{0} \mathrm{~N}$, long. $8^{0} 25^{\circ} \mathrm{E}$ ) from Zone B while Otukpo (lat $7^{0} 11^{0} \mathrm{~N}$, long $8^{0} 8^{0} \mathrm{E}$ ) and Ado (lat $6^{0} 51^{0} \mathrm{~N}$, long. $8^{0} 25^{\circ} \mathrm{E}$ ) from Zone $\mathrm{C}$, respectively (Figure 1). Three maize fields were randomly selected per LGA giving a total of 18 fields sampled altogether in the six LGAs. Farm owners were contacted during the survey and their permission secured for sampling their farms, where possible.

Field sampling procedure, maize streak spread estimation and severity determination: Sampling involved assessment of 20 plants selected randomly along a 'W-shaped' path in each field (Twizeyimana et al., 2009). All the leaves on a plant considered for assessment were observed for streak symptoms and data for the spread and severity collected per field and per plant, respectively. A total of 360 plants were evaluated in farmer's fields during the study. Disease spread and severity were determined strictly based on visual observation of streak symptoms on maize plants (Time et al., 2016). In each field, plants showing symptoms were counted among the 20 plants considered in the ' $\mathrm{W}$ ' path. Maize streak spread was then estimated as a percentage of the ratio between maize plants showing streak symptoms and the twenty plants considered in that field (Odedara et al., 2008). Streak severity on maize plants was determined on a 5- point scale, as described by Arif and Hassan (2002). In the scale, $1=$ no symptom (plants apparently healthy), $2=$ slight streaking affecting $\geq 10 \%<30 \%$ of the leaves, $3=$ streak affecting $\geq 30 \%<50 \%$ of the leaves, $4=$ stunting and severe streaking affecting $\geq 50 \%<70 \%$ of the leaves and $5=$ severe streaking with severe stunting sometimes leading to no ears formed and affecting $\geq 70 \% \leq 100 \%$ of the leaves up to death of plant. Symptoms expressed by plants were captured (pictures) during the survey. Farm size was estimated as well as the crop age, the system of cropping, spread pattern of symptoms and neighbouring field crops. Additional information such as the age and educational status of the farmers were obtained through a questionnaire.

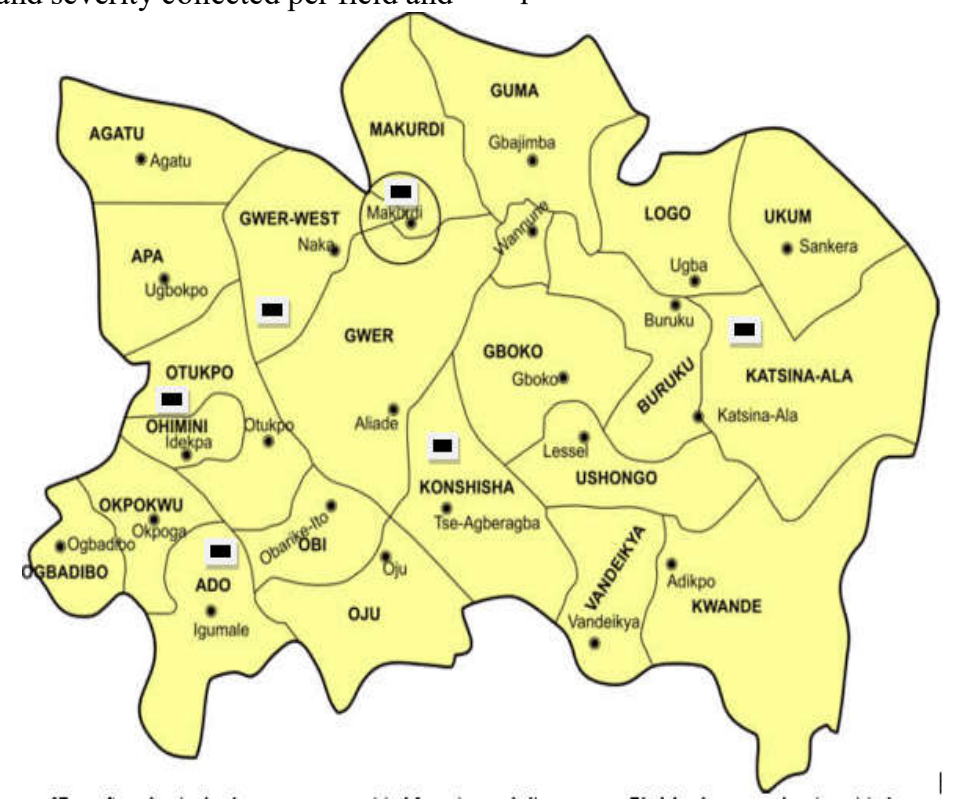

Fig 1. Map of Benue State showing local government areas visited for maize streak disease survey. Black bands represent locations visited.

Source of planting materials and experimental site: Two widely cultivated maize hybrids Oba 98, Oba super1 (Abubakar et al., 2019) and a local check were obtained from the Benue State Agricultural and Rural Development Authority. The experiment was conducted during 2016 cropping season at the College of Agronomy Research and Teaching Farm, North Core, $07^{0} \quad 41^{0} \mathrm{~N}$ and $08^{0} \quad 37^{0} \mathrm{E}$, University of Agriculture, Makurdi.
Field layout and experimental design: A $980 \mathrm{~m}^{2}$ land area was marked out for the experimental layout. The trial was laid out in a Randomized Complete Block Design (RCBD) with four replicates. Blocks were separated by $1.0 \mathrm{~m}$ and plots were separated by $0.5 \mathrm{~m}$ spaces. A block was divided further into three plots of sizes $8 \mathrm{~m}$ by $10 \mathrm{~m}$ comprising four lines of $10 \mathrm{~m}$ length, each given to a cultivar in a replication. Alleys were $1 \mathrm{~m}$ while distance between ridges was $0.75 \mathrm{~m}$. 
Crop management, diseases assessment and data collection: Within a row, three seeds were sown in a hill at $0.5 \mathrm{~cm}$ sowing depth and later thinned to two plants after emergence to attain a population density of 53,333 plants ha-1. Seedlings were applied with N P K $15: 15: 15$ fertilizer at the rate of $250 \mathrm{~kg} / \mathrm{ha}$, two weeks after sowing (WAS). The plants were left to natural infection by MSV in the field. The field was hoeweeded four times at two, five, seven and nine WAS. Disease spread estimation and severity determination were carried out as described earlier for the survey. Data on disease spread and severity in the field experiment were collected weekly for ten weeks from two weeks after sowing between August and November 2016.

Data analysis : Data collected on disease spread and severity were analyzed using analysis of variance (ANOVA) at $\mathrm{P} \leq 0.05$, while rest of the data were analyzed using descriptive statistics as described by Triola and Triola (2006).

\section{RESULTS AND DISCUSSION}

Symptoms on plant leaves in maize plots were streaks of white and yellow markings. Streaks were of different lengths on the leaf lamina; most were thin short dashes or long thin lines running parallel to the mid rib and along the veins, appearing bleached under severe conditions (Plate 1). Mildly affected plants were observed to grow and produce normally but severely infected plants either remained stunted or produced no ear. Streak symptoms on maize plant leaves in plots were typical of MSV infections on the crop and agreed with descriptions of the disease in the literature (Carlos, 1974; Darren and Dionne, 2009; Shepherd et al., 2010). Maize streak spread was generally low $(<20.0 \%)$ across the agricultural zones (Figure 1A). However, it was significantly different $(p \leq 0.05)$ among the zones with $17.2 \%$ average, although reached $19.2 \%$ at Zone B in one occasion. Spread of the disease in fields was followed by zone C with $19.0 \%$. The severity of streak was high $(3.6 \%)$ across zones, reaching its peak, 3.7 at Zone $\mathrm{C}$ while zone B (3.4) was least (Figure 1B). This was equally significant $(\mathrm{p} \leq 0.05)$ in maize plots among the agricultural zones. Disease spread among the LGAs in the State (Figure 2A) equally differed significantly $(\mathrm{p}<0.05)$. Gwer West $(21.8 \%)$ and Otukpo $(19.3 \%)$ had the highest spread. The lowest percentage spread of $12.7 \%$ and $14 \%$ were recorded in Konshisha and Katsina Ala, respectively. Streak severity was also different statistically $(\mathrm{p}<0.05)$ among the LGAs (Figure 2B). Ado and Konshisha were highest with 3.9 and 3.7, respectively while Gwer West, which was highest for disease spread was least in severity. Low disease spread $(<20 \%)$ across the study area was surprising since the farmers obtained their planting materials from anywhere - previous harvests, fellow farmers or markets. Perhaps some of such cultivars also bore some tolerant traits to the disease. Bosque-
Pérez and Buddenhagen (1999) noted that plant cultivars with tolerant traits often lower the spread of diseases in their tissues and populations. That sometimes low disease spread could partly be due to host resistance, and potential for disease spread is lower on varieties exhibiting such traits. Severity of streak in maize fields which was generally high could be the involvement of virulent strains of the virus. Karavina (2014) reported MSV-A as the most virulent strain attacking maize. Infection by MSV-A strain is identified to be the only variant causing severe MSV diseases as observed by Martins (2001).

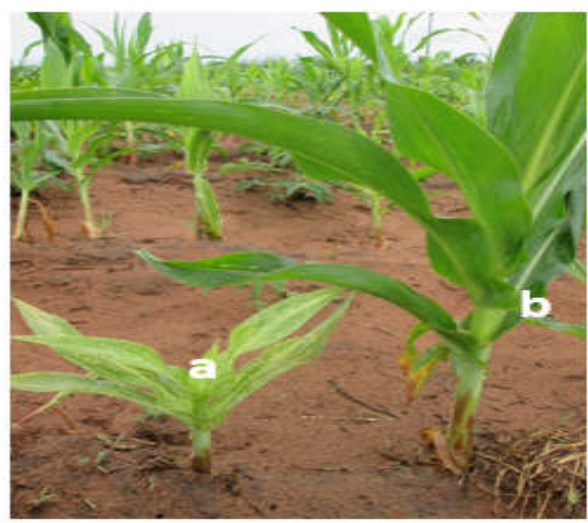

Plate 1. Maize plants (a) infected, showing characteristic streak and stunting symptoms (b) uninfected counterpart (heathy). Plant seeds were sown at the same date.

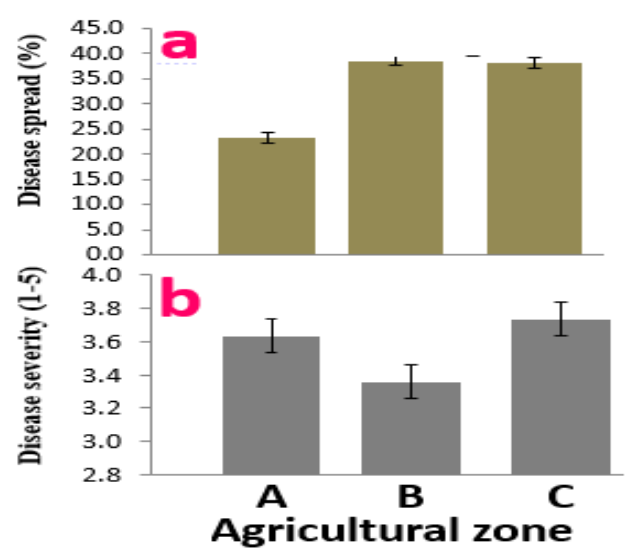

Fig 1. Maize streak spread (a) and severity (b) in the three agricultural zones surveyed during the late season cropping in Benue State.

The MSV-A strain may be the type present in Ado and Konshisha areas with highest $(>3.5)$ severities while mild virus strains may be the prevalent in Gwer West, with least disease severity. In their presentation, Storey and McClean (1930) explained that maize streak disease severity sometimes is largely dependent on the age at which the plant is infected, or the cultivar involved. Variation in severities as observed in different locations may thus, be due to some of these factors. Rose (1978) reported that in forest areas of West Africa and regions with dimodal rainfall distribution or two cropping seasons, the second crop is more severely affected by the disease. 

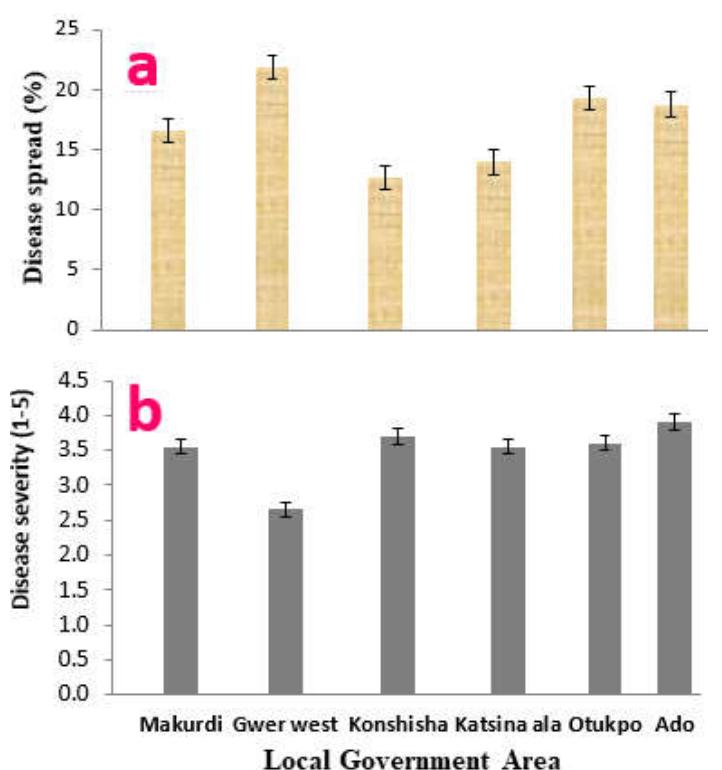

Fig 2. Spread and severity of maize streak disease in the six LGAs during the late season cropping in Benue state.

That the spread is higher for later plantings in the savannah areas with unimodal rainfall distribution. Streak severity is also influenced by inoculum dosage in plant tissues and location and could vary from season to season. Farmers encountered during the survey simply recognized their maize varieties as white or yellow seeded types. They could not correctly identify the varieties of maize they cultivated except by colour. Most of the farmers (44\%) grew both yellow and white maize together (Table 1). Almost all the maize fields visited in Makurdi and Otukpo were cultivated with both types. However, either the yellow or white type was cultivated in Gwer West and Konshisha. Average composition of maize type in terms of seed colour during surveys, being more of mixture between white and yellow seeded maize, may not be a major factor in explaining tolerance of the cultivars to the disease. Studies on MSV in maize have not been clearly focused on the crop's seed colour and tolerance to the disease, although, the gene controlling MSV tolerance (Gichuru, 2013; Mafu, 2013) and that controlling the grain colour (Xie et al., 2013) are all located on chromosome 1 . In a pairwise comparison of white and yellow conversions, Nkurunziza et al. (2019) found no significant difference $(\mathrm{P}>0.05)$ in tolerance to MSV. Mixed cropping of maize with other crops was preferred (67\%) to sole cropping of the crop. Konshisha, Otukpo and Ado practiced this system more. The source of seeds for sowing in the fields was mostly $(55 \%)$ from the previous season. None of the farmers obtained their seeds from certified sources. Good farming practices such as mixed cropping of maize with other crops could partly account for such low disease spread recorded. Cultivation of maize under mixed conditions is a common practice by the farmers in Benue, particularly the small holder farmers who aim at maximizing production. The practice also assists in lowering spread of diseases in cultivated crops. That is, the system is known to break vector activity by disrupting their mating behaviour checking disease spread (Darren and Dionne, 2009). Conversely, the practice of monocropping as the major $(66 \%)$ system of growing maize in some of the areas visited such as Gwer West coupled with the use of seeds from previous harvest for propagation, could be the reason for more spread of the disease in such areas as Otukpo. Most peasants are reported to grow traditionally open-pollinated varieties known to be susceptible, since they cannot afford MSV-tolerant hybrids (Karavina, 2014). Konshisha and Katsina Ala areas with much lower spread of the disease could be as a result of other factors like limited availability of alternative hosts to the virus or vector, weather factors or other crop management practices that are unfavorable to activities of the vector. The spread pattern of streak symptom in plots was mostly scattered (55\%) and not concentrated in maize fields. This gives a clue to the source of infection as coming from neighbouring fields and the possible involvement of insect vectors. Spread of MSV by its vector in subSaharan Africa is noted to have been sporadic in nature (Guthrie, 1977). The pattern is observed to conform to seasonal spread by the MSV vector, since the virus is not seed transmitted. Age of farmers interacted with during visits ranged from 22 and 56 years (Table 2). However, older people were encountered in Gwer West and Otukpo with age ranges of $30-56$ and $30-$ 45 , respectively. They had various levels of education (primary school to tertiary). Secondary school leavers as farmers were present in all the LGAs. None of the farmers were completely without education. Farmers in this age range and with a good number attaining tertiary education represents the active farming ages in Benue state. It also assures us of the reliability of information from them concerning farming activities in the study area. Most of the farmers had some level of education; however, their inability to correctly identify maize varieties was surprising and a serious problem. This could be attributed to non-commitment to farm work as a venture. Also worrisome is their continuous use of seeds from previous harvest perhaps as a result of their poor resource base, limiting their accessibility to certified seeds. They, hence, rely on previous harvest and open markets for seeds. Such seeds are often mixed up and may lead to wide disease spread where susceptible varieties are involved. Source of seeds for sowing among the farmers, which was predominantly (55\%) from previous seasons, has agronomic implications. Special precautions must be taken to avoid gradual changes that result to degeneration of the seed via reduced vigour, resistance to diseases, other pests and so forth. Farm sizes in the study area ranged mostly from 0.04 to 0.3 ha. This is small scale production and implies that cultivation of the crop is largely subsistent. It is rather surprising that maize is not yet a major crop in Benue, a mainly agrarian State in the country. 
Table 1. Percentage agronomic characteristic of maize, seed sources and patterns of symptom spread in the study area

\begin{tabular}{|c|c|c|c|c|c|c|c|c|c|c|c|}
\hline \multirow[b]{2}{*}{ Zone } & \multirow[b]{2}{*}{$\mathrm{LGA}^{\dagger}$} & \multicolumn{3}{|c|}{ Maize seed colour type } & \multicolumn{2}{|c|}{ Cropping system } & \multicolumn{3}{|l|}{ Seed source } & \multicolumn{2}{|c|}{ Symptom spread pattern } \\
\hline & & White & Yellow & Mixed & Monocrop & Mixcrop & Prev. harvest & Market & Certified & Scattered & Concentrated \\
\hline \multirow[t]{2}{*}{$\mathrm{A}$} & Konshisha & 33 & 66 & 0 & 0 & 100 & 33 & 66 & 0 & 66 & 33 \\
\hline & Katsina-Ala & 33 & 33 & 33 & 66 & 33 & 66 & 33 & 0 & 33 & 66 \\
\hline \multirow[t]{2}{*}{ B } & Makurdi & 0 & 0 & 100 & 66 & 33 & 66 & 33 & 0 & 66 & 33 \\
\hline & Gwer west & 66 & 33 & 0 & 66 & 33 & 66 & 33 & 0 & 66 & 33 \\
\hline \multirow[t]{3}{*}{$\mathrm{C}$} & Otukpo & 0 & 0 & 100 & 0 & 100 & 66 & 33 & 0 & 66 & 33 \\
\hline & Ado & 33 & 66 & 33 & 0 & 100 & 33 & 66 & 0 & 33 & 66 \\
\hline & Average & 28 & 33 & 44 & 33 & 67 & 55 & 44 & 0 & 55 & 44 \\
\hline
\end{tabular}

Table 2. Social characteristics of the study area

\begin{tabular}{llll}
\hline Location & $\begin{array}{l}\text { Farmer's } \\
\text { Age (Yrs) }\end{array}$ & $\begin{array}{l}\text { Farmer's } \\
\text { Education }\end{array}$ & Farm size (ha) \\
\hline Makurdi & $24-52$ & $1-2$ & $0.08-0.2$ \\
Gwer West & $30-56$ & $2-3$ & $0.06-0.1$ \\
Konshisha & $22-45$ & 2 & $0.04-0.3$ \\
Katshina - Ala & $24-56$ & 2 & $0.08-0.2$ \\
Otukpo & $30-45$ & $1-2$ & $0.04-0.1$ \\
Ado & $22-40$ & 2 & $0.04-0.03$ \\
Range & $22-56$ & $1-3$ & $0.04-0.30$ \\
\hline
\end{tabular}

*1- primary education; 2- secondary education; 3-Tertiary education.

Table 3. Spread and severity of maize streak in maize under field conditions in Makurdi

\begin{tabular}{|c|c|c|c|c|c|c|c|c|c|c|c|c|}
\hline \multirow{2}{*}{$\begin{array}{c}\text { Spread } \\
(\%)\end{array}$} & \multirow[b]{2}{*}{ Cultivar } & \multicolumn{11}{|c|}{ Weeks after gowing } \\
\hline & & 2 & 3 & 4 & 5 & 6 & 7 & 8 & 9 & 10 & 11 & Mean \\
\hline & $\begin{array}{l}\text { Local } \\
\text { Oba } 98\end{array}$ & $\begin{array}{l}7.7 \\
7.0\end{array}$ & $\begin{array}{l}10 \\
4.5\end{array}$ & $\begin{array}{l}10 \\
4.8\end{array}$ & $\begin{array}{l}11 \\
59\end{array}$ & $\begin{array}{l}13 \\
73\end{array}$ & $\begin{array}{l}14 \\
92\end{array}$ & 18 & 19 & $\begin{array}{l}22 \\
12\end{array}$ & 22 & $\begin{array}{l}14.7 \\
8.4\end{array}$ \\
\hline & Obasuperl & 7.0 & 4.3 & 4.6 & 5.6 & 6.7 & 7.6 & 8.7 & 9.2 & 11 & 13 & 7.8 \\
\hline & Mean & 7.2 & 6.3 & 6.5 & 7.5 & 9.0 & 10.3 & 11.9 & 13.1 & 15.0 & 16.0 & 10.3 \\
\hline & $\operatorname{LSD}(\mathrm{p}<0.05)$ & 9.1 & 3.1 & 1.2 & 1.8 & 0.6 & 1 & 4.4 & 2.9 & 1.4 & 1.0 & \\
\hline \multicolumn{13}{|l|}{ Severity } \\
\hline \multirow{5}{*}{$(1-5)$} & Local & 3.6 & 3.4 & 3.9 & 3.8 & 3.9 & 3.6 & 4.1 & 4 & 4.5 & 3.8 & 3.9 \\
\hline & Oba 98 & 2.7 & 3.4 & 3.4 & 3.6 & 3.7 & 3.5 & 4 & 3.5 & 3.7 & 3.7 & 3.5 \\
\hline & Obasuperl & 2.6 & 2.8 & 2.8 & 3.4 & 3.4 & 3.1 & 3.7 & 3.1 & 3 & 3.6 & 3.2 \\
\hline & Mean & 3.0 & 3.2 & 3.4 & 3.6 & 3.7 & 3.4 & 3.9 & 3.5 & 3.7 & 3.7 & 3.5 \\
\hline & $\operatorname{LSD}(\mathrm{p}<0.05)$ & 0.8 & 1.2 & 1.2 & 1.1 & 1.6 & 0.7 & 1.1 & 1.1 & 1.1 & 0.9 & \\
\hline
\end{tabular}

Status of maize streak in the experimental plots was similar when compared to the survey data; showing low $(10.3 \%)$ mean spread in maize cultivars across the plots with a high average severity through the period of study (Table 3). Maize cultivars differed significantly $(\mathrm{p} \leq 0.05)$ in the spread and severity of disease and increased progressively from the beginning (2WAS) to the end of experiment (11WAS). Streak data in the maize cultivar trial was comparable to that of the field survey. This is suggestive of the status of the disease in the study area. Some of the reasons advanced for low MSV spread and high average severity of streak in the survey may equally apply. The Local cultivar had the highest average spread of $14.7 \%$ over Oba 98 and Obasuper1 with $8.4 \%$ and $7.8 \%$, respectively. The cultivar remained most susceptible with highest weekly spread all through the period of disease assessment. Obasuper1, however, recorded the lowest weekly spread of the disease to the end of the assessment period. Average streak severity in maize experimental plots was high (3.5). This also followed similar trend as in the survey results. The Local cultivar again gave the highest mean symptom severity of 3.9, followed by Oba 98 with 3.5. Obasuper1 was still the lowest (3.2) and remained so all throughout the experiment. Weekly severity values progressed across the period of study and the trend continued to the end of study. Low values for both spread and severity as furnished by Obasuper1 maize plots are indicative of streak tolerance in the cultivar. The study has revealed that maize streak disease was low in spread, although it was present in all the surveyed locations in the State in the late season cropping. This highlights the urgent need for more information that will gear towards management of the virus in the study area.

Conclusion: The spread of maize streak in surveyed fields, although low, still calls for concern since the disease was encountered in virtually all the fields surveyed and cultivars tested. Those locations with high streak severity will be suitable as high disease spot areas for MSV screening, while those with lowest scores for severity will be appropriate for seed multiplication. The Obasuper1 cultivar, which exhibited traits of streak tolerance, may be investigated further for its resistance abilities to streak disease for use in the study area.

\section{REFERENCES}

Abubakar, AW; Manga, AA; Kamara, AY; Tofa, AI (2019). Physiological evaluations of maize hybrids under low nitrogen. Adv. Agric.: 1-6 
Arif, M; Hassan, S (2002). Evaluation of tolerance in soybean germplasm to soybean mosaic potyvirus under field conditions. J. Bio. Sc. 2: 601-604

Avav, T (2010). Development of sustainable weed management and soil improvement low-input technologies for improved food security and poverty reduction amongst resource-poor farmers. A research proposal submitted for sponsorship by the First Bank of Nigeria Professorial Chair in Agronomy, University of Agriculture, Makurdi. Pp 25.

Bosqus, NA; Buddenhagen, IW (1999). Biology of Cicadulina leafhoppers and epidemiology of maize streak virus disease in West Africa. S. Agri. J. plant soil. 6 (1): $50-55$.

Carlos, L (1974). Maize Diseases: a field guide for field identification. International Maize and Wheat Improvement Center. Information Bulletin No. 11.

Darren, PM; Dionne, NS (2009). The epidemiology, economic impact, and control of maize streak disease. Food Security 1:305-315.

Fakorede, MAB (2001). Revolutionizing Nigerian Agriculture with Golden seed. Inaugural lecture series Obafemi Awolowo University Press Limited Ile-Ife, Nigeria 82pp.

FAO (Food and Agriculture Organization of the United Nations). 2018. Maize production statistics in the Crop Production Year Book. http://faostat.fao.org/

Fatima, BJ; Abdul, SD (2005). Fungi associated with maize. Nig. J. Bot, 18: 81-86.

Guthrie, EI (1977). Virus diseases of maize in East Africa. In Williams, LE; Gordon DT; Nault LR (eds.). Proceedings International Maize Virus Disease Colloquium and Workshop, Ohio Agricultural Research and Development Center, Ohio State University, Wooster, Ohio, USA.

Gichuru, LN (2013). Breeding Investigations on Utility of Maize streak virus-Tolerant Germplasm for Hybrid Development in the Tropics. Doctoral dissertation, University of KwaZulu-Natal Pietermaritzburg, South Africa. 243pp.

IITA. 2005. International Institute of Tropical Agriculture Annual report 3: 20-32.

Iken, JE; Amusa, NA (2004). Review: Maize research and production in Nigeria. Afri. J. Biotech. 3 (6): 302-307.

Karavina, C (2014). Maize streak virus: A review of pathogen occurrence, biology, and management options for smallholder farmers. Afri. J. Agric. Res. 9 (36): 2736-2742.

Kyenpia, EO; Namo, OAT; Gikyu, SW; Ifenkwe, OP (2009). A comparative study of the biochemical composition of some varieties of maize (Zea mays) grown in Nigeria. Nig. J. Bot. 22 (1): 291-296.
Martin, DP; Willment, JA; Billharz, R; Velders, R; Odhiambo, B; Njuguna, J; James, D; Rybicki, EP (2001). Sequence diversity and virulence of maize streak virus isolates. Viro. 288: 247-255.

Mafu, NF (2013). Marker-assisted selection for maize streak virus tolerance and concomitant conventional selection for downy mildew tolerance in a maize population. MSc. Thesis, University of KwaZulu-Natal, South Africa. 177pp.

Morris, ML; Tripp, R; Dankyi., AA (1999). Adoption and impacts of improved maize production technology: A case study of the Ghana grains development project. Economics Program Paper 99-01., Mexico, D.F.: CIMMYT ISSN: 1405-7735.

Nkurunziza, G; Asea, G; Kwemoi, DB; Wasswa, P (2019). Performance and inheritance of yield and Maize streak virus disease tolerance in white maize and yellow conversions. Afri. Crp. Sc. J. 27 (1): 13 - 27.

Odedara, OO; Hughes, J; Odebode, AC; Odu, BO (2008). Multiple virus infection of lablab in Nigeria. J. Gen. Pathol. 74: 322-325.

Romney, DL; Thorne, P; Lukuyu, B; Thornton, PK (2003). Maize as food and feed in intensive smallholder systems: management options for improved integration in mixed farming systems of East and Southern Africa. Field Crps. Res. 84: 159-168.

Rose, DJW (1978). Epidemiology of maize streak disease. Ann. Rev. Entomol. 23: 259-282.

Shephered, N; Martin, DP; Walt, EV; Dent, K; Varsani, A; Rybicki, EP (2010). Maize streak virus: An old and complex 'emerging' pathogen. Mol. Plt Path. 11: 1-12.

Storey, H. H. and McClean, A. P. D. 1930. The transmission of streak disease between maize, sugarcane, and wild grasses. Ann. Appl. Biol. 17: 691-719.

Thottappilly. G., Bosque-P'erez, N.A. and Rossel, H.W. 1993. Viruses and virus diseases of maize in Tropical Africa. Plt. Pathol. 42: 494-509.

Time, I; Chikezie, CK (2016). Virus symptom types associated with fluted pumpkin (Telfairia occidentalis hook F.) in Benue state. J. Appl. Biosci. 106: 1027910285.

Triola, MW; Triola MF (2006). Biostatics for the Biological and Health sciences. Pearson Education, Boston, USA. 699pp.

Twizeyimana, M; Ojiambo, PS; Sonder, K; Ikontun, T; Hartman, GL; Bandyopadhyay, R (2009). Pathogenic variation of Phakopsora pachyrhizi infecting soybean in Nigeria. Phytopath. 99: 353-361.

Xie, C; Weng, J; Liu, W; Zou, C; Hao, Z; Li, W; Li, M; Guo X; Zhang, G; Xu, Y; Li, X; Zhang, S (2013). Zea mays (L.) P1 locus for cob glume color identified as a post domestication selection target with an effect on temperate maize genomes. The Crp. J. 1(1): 15-24. 